\title{
Collection Development in Indian Academic Libraries: An Empirical Approach to Determine the Number of Copies for Acquisition
}

\author{
Rabishankar Giri*, B.K. Sen ${ }^{* *}$ and G. Mahesh ${ }^{* * *}$ \\ *Presidency University, 86/1, College St, Kolkata, West Bengal-700 073 \\ E-mail: rsgiri11@gmail.com \\ ${ }^{* *}$ Faculty of Computer Science and Information Technology, University of Malaya, Malaysia \\ E-mail: bksen1938@gmail.com \\ ${ }^{* * *}$ National Institute of Science Communication and Resources, 14 Satsang Vihar Marg, New Delhi-110 067 \\ E-mail: gmahesh@niscair.res.in

\begin{abstract}
Collection development in academic libraries has many challenges and one of them concerns determining the number of copies of some books that are required in multiple copies in the library. In the present study, five major academic libraries in New Delhi were surveyed to understand the prevalent policies and practices on determining the number of copies of books that are required in multiple copies. It was found that there was no consistency in the approach to deciding the number of copies in the libraries studied. Further it was noted that all the libraries arbitrarily decided on the number of copies to be purchased. The paper discusses a method that has been evolved to determine the number of copies. The method has been applied in one of the academic libraries under study which when combined with other measures have been found to be more effective in determining the number of copies required.
\end{abstract}

Keywords: Collection development, academic library, library acquisition, multiple copies

\section{INTRODUCTION}

Collection development is one of the most important activities of a library and information centre, be it small and specialised, large and academic, or spread over many sites. It is the composition and size of a collection that is a major determinant of the importance, value and quality of a library. At the root of all collection development in libraries, the goal is to procure those materials that will meet the diverse needs of their users. As defined by Evans ${ }^{1}$, it is the process of making certain that the library meets the information needs of its user population in a timely and economic manner, using information resources produced both from inside and outside the organisation. This process involves several components that include, the library's mission, assessment of patron's needs, strength and weakness of the existing collection and tools for identifying the relevant and quality materials.

Over the last decade, India has witnessed a huge growth in academic institutions in the area of engineering, technology and so on ${ }^{2,3}$. These institutes charge much higher fees than the existing old university system where basic science, arts and humanities subjects are being taught. Libraries of these new institutions have taken several steps to provide superior amenities to their major stakeholders such as having a book bank that allows issuing a certain number of books for a whole semester, increasing the limit of lending materials, etc. As a consequence, libraries are to acquire multiple copies of many books. But decision on the number of copies of a book to be acquired for libraries is largely based on assumption on anticipated use, availability of funds, or even physical space.

In the $21^{\text {st }}$ century, when information explosion (both in print and electronic form) is but a common phenomenon, it is impossible to manage libraries effectively and efficiently, without precise consideration of the composition of their collection and how they are going to be developed. Thus, determining the number of copies of a book to be procured has to go beyond assumption, budget or space. Deciding the number of copies can be related to student needs that may be assessed by an empirical or evidence-based approach. 


\section{COLLECTION DEVELOPMENT PRACTICES \& PROBLEMS IN INDIAN ACADEMIC LIBRARY SYSTEM}

Collection development in an academic library is a two-way process involving the faculty and the librarian. Thus, informal communication between librarian and faculty is needed to cultivate consciously the relationship to make collection development process efficacious ${ }^{4}$. Unlike the academic libraries in the western world, Indian academic libraries hardly have subject specialist librarians. Thus, there is a lack of library staff that can be spared to liaise constantly with faculties and students to understand their needs and expectations and contribute significantly to collection development. In most of the libraries, it is still a rigid process that follows hierarchical path. So, almost all recommendations originate from faculty and rout through the heads/deans of the respective departments before reaching the library. Generally, the Library Advisory Committee (LAC) takes the final decision as to the items to be purchased for the library. In most of the Indian libraries, chief librarians and in some cases acquisition librarians are mainly responsible for collection development ${ }^{5}$. But, chief librarians are 'disadvantaged and encumbered' by other duties as they have to devote much time in many administrative and planning works and have very little time to understand the students' needs. It also leaves very little time for present day librarians to read and be updated on the needs of users. Earlier, many librarians practised the system of routing which emphasised that any new incoming material in the library should go to shelf after routing through the librarian's desk. That helped the librarians develop a broader perspective of the universe of knowledge as well as to understand the needs of the users. But, nowadays the advent of e-form of materials, diversion of attention towards the application of IT in the library, and general apathy towards reading limit majority of the librarians to practise the earlier routing system.

The acquisition librarian largely performs mere administrative functions acting like a nodal point. $\mathrm{He} / \mathrm{she}$ receives the recommendations from the faculty/students, checks the existing collection to avoid duplication, compiles the list of recommended materials, selects the vendor, places orders with vendors, etc. Many of them also lack adequate training for handling enormous and complex task of collection development. Knowledge gathered from LIS training also helps them little as hardly any library school around the globe teaches nuances and complexities of collection development ${ }^{6-8}$. Collection development is not to be seen merely as an administrative function. It is also an intellectual effort and one should view the collection as a fundamentally intellectual construct rather than exclusively as an assembly of physical objects $^{9}$. Thus, the important aspect of collection development either the intellectual contribution from the librarian or the competency 'that is inherent in many librarians' roles is an awareness of students' needs ${ }^{10}$ is lacking in our system.

The sections of the library that can be of great help to the librarian in collection development are lending/circulation and reference sections, as these witness the most interactions between users and the library. The regular interaction between the staff of these sections and users give them a perspective that may be complementary to a faculty. The faculty may know what they are assigning and what students need, but librarians (here circulation and reference librarians) know what students start out looking for before modifying their topic to use they've been able to find ${ }^{11}$. But, in many a case, the acquisition department/ librarian has a weak tie with circulation /lending/reference sections that are in the best position to understand the students /faculty demands. In this scenario, faculties are almost the sole determiner of purchasing decisions. Certainly, the faculty can and should, contribute to collection development but relying entirely on faculty may invite danger due to the following reasons.

(a) By definition and tradition, the faculties are research specialists. Their primary loyalty is more often to a profession rather than to the institution ${ }^{12}$. The promotion, merit decisionof faculties is largely based on scholarship and successful teaching. So, their scope of selecting library materials is generally narrower and inclined mostly to a specific discipline and greatly directed to specialised materials. But selection of documents for a library used heavily as an instructional laboratory (i.e., class teaching) is different from a collection used for research. The former emphasizes quantity and breadth, while the latter requires depth and selectivity. An academic library serving both functions will find the user of approval plans and librarian selector appropriate for many aspects of its collection rather than faculties ${ }^{13}$. This is also supported by several subsequent studies that observed student needs differ significantly from teaching faculty needs.

(b) The demands of preparing lectures, taking classes, advising students, grading papers, drafting grant proposals and other duties routinely burden the faculty. Additional service opportunities have little appeal for them. Many of the faculties feel that, it is a time consuming process and hardly intends to participate in it ${ }^{14}$. Even faculties rarely glance through a recommended list unless it is being consistently followed up and pursued by the librarian and also the relation between faculty and librarian play a great role ${ }^{16,16}$. 
(c) The varying degree of involvement of the faculty in collection development supports the applicability of Darwinism, i.e., the survival of the fittest. Thus, collection grows rapidly in the area where faculty members are frequent users of the library and proactively participates in material selection process. On the other hand the collection declines, where faculty members simply ignore the use of the library ${ }^{17}$. As a result the library grows disproportionately giving rise to a skewed collection instead of a balanced one. This puts enormous pressure on the librarian when a new faculty joins a discipline where collection is least developed. Thus, there is always a need to develop a core collection and that is to be maintained for the future ${ }^{18}$.

In Indian library system though stock verification is done at some intervals, collection analysis/ evaluation is hardly done. Effective collection analysis and assessment provide quantitative and qualitative data for evaluating the usefulness and utility of library holdings ${ }^{19}$. Interaction with many librarians reveals that lack of staff as well as non-availability of standard guides like WorldCat Collection Analysis tool in Indian libraries discourage them to take the burden of collection evaluation because conducting collection analysis is very expensive, time consuming and labor intensive.

In a constrained system of human resources/ professionals in Indian libraries, librarians generally look forward to the reviews for selecting library materials. But, in India, there are no authoritative reviews for course-related textbooks that are mostly needed by undergraduate students. Though in USA, such authoritative tools like Choice: Current review for academic libraries (published by ALA) plays a vital role in collection development ${ }^{1,20}$.

In this scenario procuring multiple copies of printed textbooks raises several challenges:

(a) In principle, multiple copies of a textbook should be decided where degree of fitness with the needs of users is considerably high and possibly the best fit materials as per students' needs. Otherwise, these newly procured materials will remain unused and occupy the scarce space of a library. In many libraries, it has been found that a considerable number of titles were purchased earlier in multiple copies, but they were hardly used. This obliges many librarians to move these almost unused materials either in remote storage or in a less circulated compact storage area. Unfortunately all libraries do not have offsite storage or the compact rack facility. Moreover, keeping almost unused books in multiple copies for a long time in a library hardly serves any purpose. It naturally demands weeding out of these obsolete materials. But weeding out of multiple copies of books which were hardly used is a difficult task and in all possibility may invite severe criticism from the auditors. It may also raise the question of the librarian's accountability and integrity.

(b) The situation demands a rational approach towards determining the number of copies to be purchased. Publishers for the most part work in a commercial world, and strive wholeheartedly to make profits. In a highly competitive market, they always push for more copies, and selection of material in a library generally happens more or less in an unplanned manner often mingled with political and economic interest not always above board ${ }^{21-23}$. In this situation, leaving everything (i.e., number of copies to be purchased, titles to be procured) to faculty may jeopardise a library's overall mission.

(c) It takes major chunk of the budget. Once the scarce resource is spent for one choice, the other remains unfulfilled.

\section{OBJECTIVES}

The study aims to:

(a) Understand the procedures, rules and methods followed in the acquisition of multiple copies, especially in book selection and capping the limit in respect of multiple copies; and

(b) Search for an optimal solution to the problem.

\section{METHODOLOGY}

The study was carried out in two phases. In the first phase, five academic libraries of prominent institutions established by Govt. of NCT of Delhi were surveyed where multiple copies (more than five copies) of books were procured, viz., GGS Indraprastha University, Delhi Technical University (DTU), Netaji Subhas Institute of Technology (NSIT), Indira Gandhi and Delhi Technical University for Women (IGDTUW), Ambedkar Institute of Technology. The method hinged on informal interview and interaction with the library staff and visit to libraries to understand the process of determining the limit relating to multiple copies and their recommendation process. Sometimes repeated visits were made to have a feel of the real-life situation and have talks with the users of the library selected for this purpose.

In the second phase, library usage data of one of the participating libraries (i.e., IGDTU Library) is examined to understand the subject-wise and title-wise demand of books in a course within a semester. The IGDTU library is using NewGenLib, FLOSS for integrated library management, which provides individual patron's circulation history through 
its patron's utility window ${ }^{24}$. For this purpose, books usage data of IVth semester students of Mechanical \& Automation Engineering (MAE) during the period of January 2012 to June 2012 was taken to understand the subject-wise and title-wise demands of books. This particular semester and course was selected as it is believed that the collection of the library for this course is strong enough to serve all the students effectively.

\section{RESULTS AND DISCUSSIONS}

The library staff of some of the libraries surveyed were reluctant to share the policies relating to the purchase of multiple copies and assurances had to be given that the information shared shall not be identified with the libraries concerned. Table 1 summarises the processes practised in the five libraries. From the data it is clear that an arbitrary approach has been followed to cap the limit. There is hardly any operation research approach to justify the capping limit. Librarians maintain that they are not always in a position to understand the likely demand of a subject or a particular title within the subject. Thus, a collective decision in the LAC meeting was followed finally to determine the student book ratio. But, as pointed out earlier when most of the faculties feel that participation in collection development is a thankless job ${ }^{4}$, then the effectiveness of such collective decision where decision makers are reluctant to put their critical thought will inherently attract many questions.
The data also reveal's that faculties are almost the sole recommenders. In majority of the libraries surveyed, there is hardly any process to encourage their major stakeholders, i.e., the students of the institute to participate in the process. Some libraries still follow the highly rigid process of recommendation. Thus, when a student wants to recommend a book, he/she has to forward it through the Head of the Department. This, in many instances, discourages them to participate actively in the recommendation process.

Some librarians raise a genuine concern. When a faculty member recruited for a short-time recommends purchase of multiple copies of a textbook, the librarian purchases the multiple copies. After the teacher leaves, a new faculty member joins and recommends multiple copies of another textbook to replace the earlier one. Thus, the previous book loses its importance and passes into the realm of permanent non-use or reduced use as most students demand the book, the new teacher has recommended. More often than not, teachers recommend certain books in multiple copies, which find hardly any readers. Students' feedbacks at times show that the teacher had forgotten to suggest the newly arrived books in the class.

When a particular field is highly evolving and every two to three years, a new edition of the book is hitting the market, then, there is hardly any taker of the old edition of the books. Purchasing a large

Table 1. Maximum limit of multiple copies of books and the recommendation process

\begin{tabular}{|c|c|c|}
\hline $\begin{array}{l}\text { Lib- } \\
\text { rary }\end{array}$ & Limit & Recommendation process \\
\hline 1. & $\begin{array}{l}\text { Maximum numbers of copies are determined on the basis of } \\
\text { student strength for a particular course. This policy has been } \\
\text { changed over the years. } \\
\text { Initially, Student : Book }=1: 1 \\
\text { Then, Student : Book }=4: 1 \\
\text { Presently, Student : Book }=2: 1 \\
\text { In addition, one instructor's copy can be acquired. }\end{array}$ & $\begin{array}{l}\text { Teachers are almost the sole recommender. Research } \\
\text { scholars recommend Occasionally and students rarely. } \\
\text { Library staff recommend rarely except books related to Li- } \\
\text { brary and Information Science. There is no policy/method } \\
\text { of encouraging student participation. If a student wants to } \\
\text { recommend, it should be forwarded through the Head of the } \\
\text { Department }\end{array}$ \\
\hline
\end{tabular}
When a title is prescribed for multiple courses, up to a maximum of three copies can be obtained for instructors. Final decision is taken by the Library Advisory Committee.

2. Student : Book ratio $=4: 1$

Final determination left to Library Committee.

3. Student: Book ratio $=5: 1+$ one instructor copy

Teachers are major recommenders but research scholars also take part in recommendation process. Students hardly recommend. The library staff do it occasionally.

Teachers are major recommenders. Students are also encouraged to recommend online. The library staff also recommend a significant number of books

4. A maximum of $30 \%$ of the total students needed the book. Final decision on cap is left to the Library Committee

Teachers are almost the sole recommender. A student can recommend when a prescribed book in a class is not available in the library. The recommendation needs to be forwarded through the Head of the Department

5. Deciding the number of copies is left to Library Advisory Com- Teachers are almost the sole recommenders mittee. The maximum can go up to $3: 1$ as Student: Book ratio. 
Table 2. Subject-wise book demand behaviour of IVth semester students of MAE during January 2012 to June 2012

\begin{tabular}{|c|c|c|c|c|}
\hline Subjects & $\begin{array}{l}\text { Number of times } \\
\text { books issued on } \\
\text { the subject }\end{array}$ & $\begin{array}{l}\text { Number of reserva- } \\
\text { tions made on the } \\
\text { books on the subject }\end{array}$ & $\begin{array}{l}\text { Total Demand (TD) = } \\
\text { Issue + Reservation }\end{array}$ & $\begin{array}{l}\% \text { of Total Demand }=(\text { TD } \\
\text { of the subject } / \text { TD of all } \\
\text { subjects }) * 100\end{array}$ \\
\hline $\begin{array}{l}\text { Kinematics \& Dynamics } \\
\text { of Machines }\end{array}$ & 192 & 24 & 216 & 13.82 \\
\hline Heat Transfer & 288 & 8 & 296 & 20.73 \\
\hline Manufacturing Machines & 293 & 31 & 324 & 18.94 \\
\hline Operation Research & 203 & 7 & 210 & 13.44 \\
\hline LAN \& Networking & 275 & 11 & 286 & 18.3 \\
\hline Others* & 93 & 10 & 103 & 6.59 \\
\hline
\end{tabular}

*Others is used for the subjects that are not part of the course work for the semester

number of copies in these areas not only wastes money but also reduces the shrinking space.

With this background, library usage data of IVth year student of Mechanical \& Automation Engineering (MAE) during the period of January 2012 to June 2012 was taken to understand the subject-wise and title-wise demands of books.

From Table 2 it is clear that there is a considerable variation of demands of books among the subjects studied in the semester. This may be due to one's inclination/preference towards the specific subjects or the perceived importance of the subjects among the students for the semester. Whatever it may be, knowledge of this demand variation among the subjects studied in a semester of a course will help librarians to take informed decision for collection development. The title-wise demand of the books of above six subjects is shown in Table 3 . The title-wise usage data of each subject reveals that undergraduate students primarily use a few selective text books within the subject rather than wide spectrum of titles within the subject. Thus, it may be argued that only a few titles are required in multiple copies to provide better support to students rather than procuring a wide range of titles in multiple copies which has been observed by the authors in the participating libraries.

Thus, the maximum number of copies of a book to be purchased may be decided mathematically basing the anticipated requirement/usage statistics of the book. The formula can be based on the total number of students of a course for a given semester and the maximum loan limit to students. Suppose $N$ is the total number of students in a given semester of a course in a university and each student can be issued a maximum of $P$ number of books. Hence, at any given point of time, a maximum of NP number of books will be required to serve the students. Let, $S$ denotes the number of subjects taught in the given semester and $T_{j}$ denotes the weightage of the subject correspond to the subject $S_{i}$, and then the maximum number of books required for the subject $S_{i}$ is given by

$$
\left\{\left(\frac{N P}{\sum_{\substack{i=1 \\ j=1}}^{n} S i T j}\right) * T j\right\}
$$

Here, it is to be mentioned that weightage of a subject $\left(T_{j}\right)$ among the subjects taught (i.e., $S$ where $i=1,2,3, \ldots n)$ in a course of a semester is determined by the ratio of demands books in that particular subject with respects to other subjects taught in that particular course. Let us Suppose:

Total number of students in a semester $(N)=60$

Maximum no. of books a student can borrow

$$
(P)=6
$$

No. of subjects taught in a semester $(S)=6$, say $S_{1}, S_{2}, S_{3}, S_{4}, S_{5}$ and $S_{6}$

Let, the corresponding weightage $T$ of the subject $S_{i}$ according to the ratio of demands of books among the subjects taught in the semester is as follows:

$T_{1}: T_{2}: T_{3}: T_{4}: T_{5}: T_{6}=4: 3: 2: 4: 2: 3$

Hence, subject $S_{1}$ requires $\left\{\left(60^{*} 6\right) / 18\right\}^{*} 4=80$ books maximum

Here, it is assumed that at any point of time, lending of books among the subjects hardly cross the demand ratio derived from consolidated ratio of demands of books among the subjects.

Further extending the formula (1), if for a subject, $X_{i}$ number of book titles is the prescribed text books and $W_{j}$ is the weightage given to the title $X_{i}$, and then the maximum limit for multiple copies of for a given title $X_{i}$ should be

$$
\left[\left\{\left(\frac{\left(\frac{N P}{\sum_{i=1}^{n} S i T j}\right) * T j}{j=1}\right)\right] * W j\right.
$$


Table 3. Majorly used books within the subjects of IVth semester students of MAE during January 2012 to June 2012

\begin{tabular}{|c|c|c|c|c|c|}
\hline Subject & Titles of the book & Issued & Reserved & $\begin{array}{l}\text { Total } \\
\text { demand }\end{array}$ & $\begin{array}{l}\text { Demand for majorly } \\
\text { used books as a } \% \text { of } \\
\text { total demand (given in } \\
\text { Table } 2 \text { ) in the subject }\end{array}$ \\
\hline \multirow{5}{*}{$\begin{array}{l}\text { Kinematics \& } \\
\text { Dynamics of Ma- } \\
\text { chines }\end{array}$} & Theory of machines / SS Rattan & 52 & 6 & 58 & \\
\hline & $\begin{array}{l}\text { Theory of mechanisms and machines / } \\
\text { AmitabhaGhosh }\end{array}$ & 46 & 7 & 53 & \\
\hline & $\begin{array}{l}\text { Theory of machines and mechanisms / P. L. } \\
\text { Ballaney }\end{array}$ & 24 & 8 & 32 & \\
\hline & Theory of machine / R.S. Khurmi & 22 & 2 & 24 & \\
\hline & \multicolumn{3}{|c|}{ Sum of demands of majorly used books in the subject $=$} & 167 & $77.3 \%$ \\
\hline \multirow[t]{4}{*}{ Heat Transfer } & Thermal engineering/ Ballaney & 102 & 11 & 113 & \\
\hline & Engineering thermodynamics / P.K. Nag & 96 & 2 & 98 & \\
\hline & Heat and mass transfer/ R. Yadav & 34 & 1 & 35 & \\
\hline & \multicolumn{3}{|c|}{ Sum of demands of majorly used books in the subject $=$} & 246 & $83.1 \%$ \\
\hline \multirow[t]{4}{*}{$\begin{array}{l}\text { Manufacturing } \\
\text { Machines }\end{array}$} & $\begin{array}{l}\text { Elements of workshop technology / S.K. } \\
\text { Hajra Choudhury }\end{array}$ & 116 & 9 & 125 & \\
\hline & $\begin{array}{l}\text { A course in workshop technology / B.S. } \\
\text { Raghuwanshi }\end{array}$ & 77 & 6 & 83 & \\
\hline & $\begin{array}{l}\text { Manufacturing technology : Metal cutting } \\
\text { and machine tools / P.N. Rao }\end{array}$ & 32 & 7 & 39 & \\
\hline & \multicolumn{3}{|c|}{ Sum of demand of majorly used books in the subject $=$} & 247 & $76.2 \%$ \\
\hline \multirow{4}{*}{$\begin{array}{l}\text { Numerical Analy- } \\
\text { sis \& Program- } \\
\text { ming }\end{array}$} & $\begin{array}{l}\text { Numerical methods in engineering and sci- } \\
\text { ence / B.S. Grewal }\end{array}$ & 59 & 4 & 63 & \\
\hline & Numerical methods / E. Balagurusamy & 17 & & 17 & \\
\hline & $\begin{array}{l}\text { Computer programming and numerical } \\
\text { analysis : An integrated approach / N. Datta }\end{array}$ & 10 & & 10 & \\
\hline & \multicolumn{3}{|c|}{ Sum of demand of majorly used books in the subject $=$} & 90 & $70.3 \%$ \\
\hline \multirow[t]{4}{*}{$\begin{array}{l}\text { Operation Re- } \\
\text { search }\end{array}$} & $\begin{array}{l}\text { Operations research : an introduction / } \\
\text { Hamdy A. Taha }\end{array}$ & 66 & 2 & 68 & \\
\hline & $\begin{array}{l}\text { Quantitative techniques in management / } \\
\text { N.D. Vohra }\end{array}$ & 46 & 12 & 58 & \\
\hline & Operations research / R. Panneerselvam & 54 & 2 & 56 & \\
\hline & \multicolumn{3}{|c|}{ Sum of demand of majorly used books in the subject $=$} & 182 & $86.7 \%$ \\
\hline \multirow[t]{4}{*}{ LAN \& Networking } & Computer networks / Andrew S. Tanenbaum & 92 & 6 & 98 & \\
\hline & $\begin{array}{l}\text { Data communications and networking / Beh- } \\
\text { rouz A. Forouzan }\end{array}$ & 84 & 5 & 89 & \\
\hline & $\begin{array}{l}\text { Data and computer communications / Wil- } \\
\text { liam Stallings }\end{array}$ & 33 & & 33 & \\
\hline & \multicolumn{2}{|c|}{ Sum of demand of majorly used books in the subject $=$} & & 220 & $76.7 \%$ \\
\hline
\end{tabular}

Here, it is to be noted that weightage $\left(W_{j}\right)$ of a book title among the prescribed titles (i.e., $X$ where $i=1,2,3 \ldots . n)$ in a subjects is determined by the preference ratio of majorly used individual titles in that subject.
Hence, in continuation with the example given at $A$, let the subject $S_{1}$ corresponding to subject weightage $T_{1}$ has 5 prescribed textbooks say $X_{1}$, $X_{2}, X_{3}, X_{4}, X_{5}$ and their corresponding weightage $W_{1}: W_{2}: W_{3}: W_{4}: W_{5}=4: 2: 3: 4: 3$. Hence, the maximum 
limit for multiple copies for a title say $X_{1}$ is equal to $(80 / 16)^{*} 4=20$ copies.

Here, it is assumed that at any point of time, demand of titles in a subject hardly cross preference ratio of titles in that subject.

\section{MEASURES APPLIED IN IGDTUW LIBRARY}

The library is striving to follow the above formula in determining the maximum limit as to the number of copies of a particular title. The above mathematical formula is found to be very useful when library receives request to procure several titles in a subject. While applying the above formula, the practical limitation arises in determining the weightage of a subject of a course in a given semester. For this purpose, the library has adopted a mixed policy. Whenever a new subject/course is introduced, the library requests the course coordinator/concerned faculty to indicate atmost three major titles in the subject that may be primarily used by the students for the subject, so that they may be procured in multiple copies. Even in that case, the library initially purchases atmost five copies and after observing the students needs, it goes for additional copies.

For books in a subject that are already being taught in a semester and available in the library, the usage data of consecutive two years for the semester are used in determining the weightage of the subjects when a large number of copies of several titles are recommended for procurement.

The other problem arises when a given title is required by students of other courses at the same time. For example, computer language programming by $C$ was needed by the students of $3^{\text {rd }}$ semester of Mechanical \& Automation Engineering (MAE) students as well as Electronics \& Communication Engineering (ECE) students at the same time. In that case, maximum value for MAE for $3^{\text {rd }}$ semester and maximum value or ECE for $3^{\text {rd }}$ semester has been compared and higher value has been taken as maximum limit for purchasing initially. After that, feedbacks from circulation department as well as from students were collected. When it was observed that more copies were needed, additional copies were purchased phase-wise keeping demand structure in mind up to a maximum to the sum total of requirements of the two departments. But it is observed that rarely the sum total of two departments' requirement is needed as there are other books on the same subject that supplement the students' need. In addition, to ensure the availability of most needed books at any time in the library for consultation, one copy (generally instructor's copy) is kept in the frequently used book section. As it is only for consultation, it is not issued.
An alternate proposal of purchasing e-copy of books (wherever available) to avoid acquisition of multiple copies were also in consideration. But e-copy of many prescribed textbooks is not available. Majority of the university-prescribed textbooks published by the Indian publishers are not available in e-form. A small experiment was carried out to assess the usability of the e-book. In the experiment, e-copies of the four textbooks that were on heavy demand were kept in the library server for downloading and using within the campus. It was observed that though there was significant downloading of the e-copy, but students' demands for the print version almost remained the same. From the feedback of students, it was found that they use e-copy only when the hard copy of the books was not available and most of the student prefer reading from the printed version of the textbooks.

To reduce dependency on the faculty, several communication channels are being used to reach students and researchers. These include recommendation through OPAC; group e-mailing system with a link to e-recommendation form created in Google Docs, social networking site (e.g. Library Facebook page, Twitter); and a permanent link in library blog. As a result, it is found that there is about three-fold jump in student participation in book recommendation process $^{25}$.

Whenever a new title in multiple copies (more than three copies) is recommended by a temporary faculty, the scenario of library holdings on the same subject is presented to the concerned faculty and then efforts are made to collect data on availability of other titles on the same subject in the market as well as from other peer libraries. In many instances, the library staff of peer libraries (e.g., the library of DTU) supplies valuable information relating to much used titles on the subject.

Thereafter, the total scenario is presented to the dean/head of the respective department. If they still insist for more copies, the library starts purchasing a maximum of five copies initially and then purchases phase-wise up to the limit of maximum value provided by the formula by observing the student demands. In a fast evolving discipline like fuzzy system and neural networks of computer science, when more than three copies of books are recommended, the library has taken the policy of phase-wise purchasing of books and extensive diversification of titles. This automatically downs maximum value as $X$ value increases with extensive diversifications.

\section{CONCLUSIONS}

Procurement of multiple copies of books demands the librarian to take ownership of the collection 
development. As at the end of the day, it is the librarian who is held responsible for the quality and performance of the library's collection. If the collection is deemed inadequate by accrediting agencies, it is the librarian rather than the faculty will be asked to take the appropriate steps to improve it. The librarian/ acquisition staff should also make conscious and continuous efforts to harness the expertise of the faculty as it is vital to the health of the collection ${ }^{26}$. Continuous interaction with faculty and students as well as regular scanning of incoming materials have the potential to give them broader perspective as well as enlighten them about the new developments which eventually help them to play the leading role in collection development. It also underscores the necessity of subject librarians in Indian academic library system. Thus, instead of being a mere administrative functionary, librarians can intellectually contribute to the health of the collection. Also, there should be local training programmers on collection development, so that new entrants as well as existing professionals in the library field may be better prepared to develop their collections as practicing librarians ${ }^{18,27}$. In addition, it demands optimal use of current advancements in ICT especially developments in web to reach all the stakeholders in real time. Above all, determining the maximum number of copies of a book required for the library calls for better understanding of users' need as well as application of operational research techniques.

\section{REFERENCES}

1. Evans, G.E. Developing library and information center collections. Libraries Unlimited, Colorado, 2004.

2. Banerjee, R. \& Mulley, V. P. Engineering education in India. Indian Institute of Technology, Mumbai, 2008. http://casi.sas.upenn.edu/system/files/En gineering $\% 2 \mathrm{BEducation} \% 2 \mathrm{Bin} \% 2 \mathrm{BIndia} \% 2 \mathrm{BDec}$ 1608-1.pdf. (accessed on 1 February 2013).

3. AICTE. Approval process handbook (2012-13). All India Council for Technical Education, New Delhi, 2012. http://www.aicte-india.org/downloads/ approval_process_12_13_051011.pdf (accessed on 1 February 2013).

4. Chu, F.T. Librarian-faculty relations in collection development. J. of Acad. Lib., 1997, 23(1), 1520.

5. Khan, A.M. Managing collection development and organization in globalising Indian university libraries. Collection Building, 2010, 29(1), 15-21.

6. Sorgenfrei, R. \& Hooper-Lane, C. Book selection responsibilities for the reference librarian: Professional benefit or burden? Lib. Coll., Acqui. and Tech. Serv., 2001, 25(2), 171-78.

7. Forte, E., et al., Developing a training program for collection managers. Lib. Coll., Acqui. and Tech. Serv., 2002, 26(3), 299-306.

8. Johnson, P. Fundamentals of ccollection development and management. American Library Association, Chicago, 2014.

9. Galbreath, R. Nailing Jell-O to the wall? Collection management in the electronic era. North Carolina Libraries, 1997, 55(1), 18-21.

10. Connell, T. H. Comparing the circulation of library materials ordered by faculty and librarians. Collection Management,1991, 14(1/2), 73-84.

11. Kohn, K.C. Usage-based collection evaluation with a curricular focus. Coll. \& Res. Lib., 2013, 74(1), 85-97.

12. Dinkins, D. Circulation as assessment: Collection development policies evaluated in terms of circulation at a small academic library. Coll. \& Res. Lib., 2003, 64(1), 46-53.

13. Gorman, G.E. \& Howes, B. R. Collection development for libraries. Bowker-Saur, London, 1989.

14. Joswick, K.E. \& Stierman, J.K. Perception vs. use: Comparing faculty evaluations of journal titles with faculty and student usage. J. of Acad. Lib., 1995, 21(6), 457-58.

15. Yang, E.L. Psychology collection review: A cooperative project between librarians and departmental faculty members. Collection Management, 1990, 13(3), 45-53.

16. Arendt, J. \& Lotts, M. What liaisons say about themselves and what faculty say about their liaisons, a US survey. Portal: Lib. and Acad., 2012, 12(2), 155-77.

17. Kim, U.C. Participation of teaching faculty in library book selection. Collection Management, 1981, 3(4), 333-52.

18. Bodi, S. \& Maier-O'Shea, K. The Library of Babel: Making sense of collection management in a postmodern world. Journal of Acad. Lib., 2005, 31(2), 143-50.

19. Henry, E.; Longstaff, R. \& Van Kampen, D. Collection analysis in an academic library. Collection Building, 2008, 27(3), 113-17.

20. Lawson, K.; King, C. \& Matava, T. Interdisciplinary on campus: How the publishing world is responding. Collection Building, 2012, 31(1), 4-10.

21. Frazier, K. Collection development and professional ethics. J. of Lib. Admin., 1999, 28(1), 33-46.

22. Kertesz, C. The Unwanted Gift: When saying 
"no thanks" isn't enough. American Libraries, 2001, 32(3), 34-36.

23. Clayton, P. \& Gorman, G.E. Managing information resources in libraries. Collection management in Theory and Practice. Facet Publishing, London, 2006.

24. Giri, R. NewGenLib 3: An integrated open source library management system that makes your library visible in web. Library Hi Tech News, 2012, 29(10), 4-12.

25. Giri, R.; Kar, D.C. \& Sen, B.K. The effect of Facebook adoption in an academic library. World Digital Library, 2014, 7(2),

26. Neville, R.; Williams III, J. \& Hunt, C.C. Facultylibrary teamwork in book ordering. Coll. \& Res. Lib., 1998, 59(6), 523-32.

27. Adekanmbi, A.R. \& Boadi, B.Y. Problems of developing library collections: A study of colleges of education libraries in Botswana. s, 2008, 24(4), 275-88.

\section{About the Authors}

Mr Rabishankar Giri is working as Assistant Librarian at Presidency University, Kolkata. His research interest centres on investigating how knowledge brokers in complex, multimodal communication settings use information systems to transfer knowledge and influence others. He has written articles in several Scopus indexed journals. Prior to joining the university, he held as in-charge library automation, digital library and library 2.0 in Indira Gandhi Delhi Technical University for Women, Delhi. He worked as Head-Photo Archives, Times of India, Delhi; In-charge-Periodicals and Database, Institute for Defence Studies and Analyses, the premier think tank in India's Defence and Security Studies.

Dr Bimal Kanti Sen graduated in Science with Distinction and obtained his Diploma in Library Science from the University of Calcutta. He obtained his Master's degree in Library in Information Science from the University of Delhi and PhD from Jadavpur University working on the history of Indian scientific periodicals. He served INSDOC for more than 30 years working on various capacities and heading among others Russian Science Information Centre; National Centre on Bibliometrics; Education and Training Division and National Science Library. He served the University of Malaya as a Visiting Professor from 1995 to 1999.

Dr G. Mahesh is Principal Scientist at CSIR-National Institute of Science Communication and Information Resources (NISCAIR), New Delhi. He is currently Head, National Science Library and the Coordinator of the National Knowledge Resource Consortium (NKRC), a project that facilitates online access to information resources to all CSIR and DST labs. He has about 20 papers published in international and national journals. He is also the Editor of Annals of Library and Information Studies. 